\title{
The impact of moderate wine consumption on the risk of developing prostate cancer
}

This article was published in the following Dove Press journal:

Clinical Epidemiology

Mihai Dorin Vartolomei, ${ }^{1,2, *}$

Shoji Kimura, ${ }^{2,3, *}$

Matteo Ferro, ${ }^{4}$

Beat Foerster, ${ }^{2,5}$

Mohammad Abufaraj, 2,6

Alberto Briganti, ${ }^{7}$

Pierre I Karakiewicz, ${ }^{8}$

Shahrokh F Shariat ${ }^{2,9,10,11}$

'Department of Cell and Molecular Biology, University of Medicine and Pharmacy, Tirgu Mures, Romania; ${ }^{2}$ Department of Urology, Medical University of Vienna, Vienna, Austria; ${ }^{3}$ Department of Urology, Jikei University School of Medicine, Tokyo, Japan; ${ }^{4}$ Division of Urology, European Institute of Oncology, Milan, Italy; ${ }^{5}$ Department of Urology, Kantonsspital Winterthur, Winterthur, Switzerland; ${ }^{6}$ Division of Urology, Department of Special Surgery, Jordan University Hospital, The University of Jordan, Amman, Jordan; ${ }^{7}$ Department of Urology, Vita Salute San Raffaele University, Milan, Italy; ${ }^{8}$ Cancer Prognostics and Health Outcomes Unit, University of Montrea Health Centre, Montreal, Canada; ${ }^{9} \mathrm{Karl}$ Landsteiner Institute of Urology and Andrology, Vienna, Austria; ${ }^{10}$ Department of Urology, University of Texas

Southwestern Medical Center, Dallas, TX, USA; "Department of Urology, Weill Cornell Medical College, New York, NY, USA

*These authors contributed equally to this work

Correspondence: Shahrokh F Shariat Department of Urology, Comprehensive Cancer Center, Medical University of

Vienna, Vienna General Hospital, Währinger Gürtel 18-20, A-1090 Vienna, Austria

$\mathrm{Tel}+43$ | 4040026150

Fax +43 I 4040023320

Email: shahrokh.shariat@meduniwien.ac.at
Objective: To investigate the impact of moderate wine consumption on the risk of prostate cancer $(\mathrm{PCa})$. We focused on the differential effect of moderate consumption of red versus white wine.

Design: This study was a meta-analysis that includes data from case-control and cohort studies. Materials and methods: A systematic search of Web of Science, Medline/PubMed, and Cochrane library was performed on December 1, 2017. Studies were deemed eligible if they assessed the risk of $\mathrm{PCa}$ due to red, white, or any wine using multivariable logistic regression analysis. We performed a formal meta-analysis for the risk of PCa according to moderate wine and wine type consumption (white or red). Heterogeneity between studies was assessed using Cochrane's Q test and $I^{2}$ statistics. Publication bias was assessed using Egger's regression test. Results: A total of 930 abstracts and titles were initially identified. After removal of duplicates, reviews, and conference abstracts, 83 full-text original articles were screened. Seventeen studies (611,169 subjects) were included for final evaluation and fulfilled the inclusion criteria. In the case of moderate wine consumption: the pooled risk ratio (RR) for the risk of PCa was 0.98 $(95 \%$ CI $0.92-1.05, p=0.57)$ in the multivariable analysis. Moderate white wine consumption increased the risk of PCa with a pooled RR of 1.26 (95\% CI 1.10-1.43, $p=0.001)$ in the multivariable analysis. Meanwhile, moderate red wine consumption had a protective role reducing the risk by $12 \%$ (RR $0.88,95 \%$ CI $0.78-0.999, p=0.047)$ in the multivariable analysis that comprised 222,447 subjects.

Conclusions: In this meta-analysis, moderate wine consumption did not impact the risk of PCa. Interestingly, regarding the type of wine, moderate consumption of white wine increased the risk of $\mathrm{PCa}$, whereas moderate consumption of red wine had a protective effect. Further analyses are needed to assess the differential molecular effect of white and red wine conferring their impact on PCa risk.

Keywords: wine, prostate cancer, alcohol, risk of cancer, meta-analysis

\section{Introduction}

Prostate cancer $(\mathrm{PCa})$ is the most commonly diagnosed cancer among men in the USA with an estimated 161,360 new cases in $2017 .{ }^{1}$ Worldwide, it is the second most common cancer and the sixth cause of cancer death among men, ${ }^{2}$ with an estimated 1.1 million cases and 307,000 deaths in $2012 .{ }^{3}$ There are well-established risk factors for PCa, such as family history, ${ }^{4,5}$ hereditary genes, ${ }^{6}$ racial/ethnic background (eg, African ethnicity), ${ }^{7}$ and age. Also, a wide variety of exogenous/environmental/ lifestyle factors have been shown to impact the risk of PCa development and progression. ${ }^{8}$ For example, alcohol intake has been recently suggested as a risk factor for PCa 
development in a meta-analysis that included 27 studies showing a significant dose-response relationship between the level of alcohol intake and the risk of $\mathrm{PCa} .{ }^{9}$ On the other hand, a large prospective European cohort study failed to observe an association between alcohol consumption and PCa risk. ${ }^{10}$ Both studies did not assess the type of alcohol consumption. Despite association between alcohol intake and PCa risk, the effect of wine consumption on PCa risk is not yet fully understood. Furthermore, association between wine consumption and risk of PCa demands further investigation as several studies have suggested that polyphenols from red wine have a chemoprotective role in PCa cell lines. ${ }^{11,12}$

Therefore, we hypothesized that wine, specifically red wine, has a protective effect on PCa development. To test this hypothesis, we performed a meta-analysis assessing the effect of moderate wine consumption on PCa in a first step and then that of red and white wine differentially.

\section{Materials and methods}

A systematic search of Web of Science, Medline/PubMed, and Cochrane library was performed using the terms "wine" and "prostate cancer" on December 1, 2017. All original articles that fulfilled the inclusion criteria were included. We performed additional cross-checking of reference lists, including those of previous meta-analyses and "handsearched" for additional references in the selected articles, reviews, and meta-analyses reporting on the topic.

Informed consent was not required for this type of study.

\section{Inclusion and exclusion criteria}

The PICOS (Population, Intervention, Comparator, Outcome and Study design approach was utilized to define study eligibility according to the Preferred Reporting Items for Systematic Reviews and Meta-Analysis (PRISMA) criteria (www.prisma-statement.org). ${ }^{13}$ Studies were considered eligible if they assessed the risk of PCa due to red and white wine and wine in general using multivariable logistic regression analysis in the general population or compared with a control group of individuals without PCa. For each selected study, the following items were recorded: first author's name, year of publication, country, number of patients, age, and variables used in the multivariable analysis, risk ratios (RRs) of PCa in multivariable analysis, dose of wine and followup in case of cohort studies. Two independent investigators (MDV and SK) assessed study quality using the NewcastleOttawa Scale (NOS) $)^{14}$ for cohort studies. A total score of 5 or less was considered low; 6-7 was considered intermediate, and 8-9 was considered high quality. Most included studies had intermediate and high quality score according to NOS (Figure S1).

\section{Statistical analysis}

We performed a formal meta-analysis for the risk of PCa according to moderate wine consumption and moderate consumption of type of wine (white or red). RRs with their 95\% CIs from each study were used to calculate pooled RRs. Pooled estimates were calculated with the fixed effect model, if no significant heterogeneity was identified; alternatively, the random effect model was used when significant heterogeneity was detected. Statistical heterogeneity was defined based on Cochrane's Q $p$-value or $I^{2}$ statistics. We performed "leave-one-out" sensitivity analysis. To evaluate publication bias, Egger linear regression and funnel plots were examined. In case of reporting only RRs for low- and high-risk PCa, we included in the meta-analysis the RRs for high-risk PCa. Statistical analyses were performed using Stata 11.0 statistical software (Stata Corp., College Station, TX, USA).

\section{Results}

A total of 930 abstracts and titles were initially identified. After removal of duplicates, reviews, and conference abstracts, 83 full-text original articles were screened. Finally, 17 studies (a total of 611,169 subjects) were included for final evaluation fulfilling the inclusion criteria. ${ }^{15-31}$ The PRISMA flow chart summarizing the process of study selection is shown in Figure 1. Potential publication bias was examined by both a funnel plot and an Egger's test and we did not find any publication bias (Figure 2). Assessment of the main studies biases are shown in the risk bias table (Figure S2).

\section{Effect of moderate consumption of wine on PCa risk}

Overall, 14 studies (455,413 subjects) fulfilled the inclusion criteria regarding moderate wine consumption and risk of PCa (6 cohort and 8 case-control studies). ${ }^{15-22,24,26,27,29-31}$ The main characteristics of the studies, as well as dose of wine consumption, are shown in Table 1 . In the first meta-analysis, we included all the studies regardless of design. The pooled $\mathrm{RR}$ for the risk of PCa was 0.98 (95\% CI 0.92-1.05, $p=0.57$ ) in the multivariable analysis (Figure 3). The Cochrane's Q test $\left(\chi^{2}=17.6 ; p=0.19\right)$ and $I^{2}$ test $\left(I^{2}=23.8 \%\right)$ did not show a significant heterogeneity. The funnel plots identified one study over the pseudo 95\% CI (Figure 2A). Furthermore, we performed a second meta-analysis in which we included only cohort studies (438,302 subjects from which 


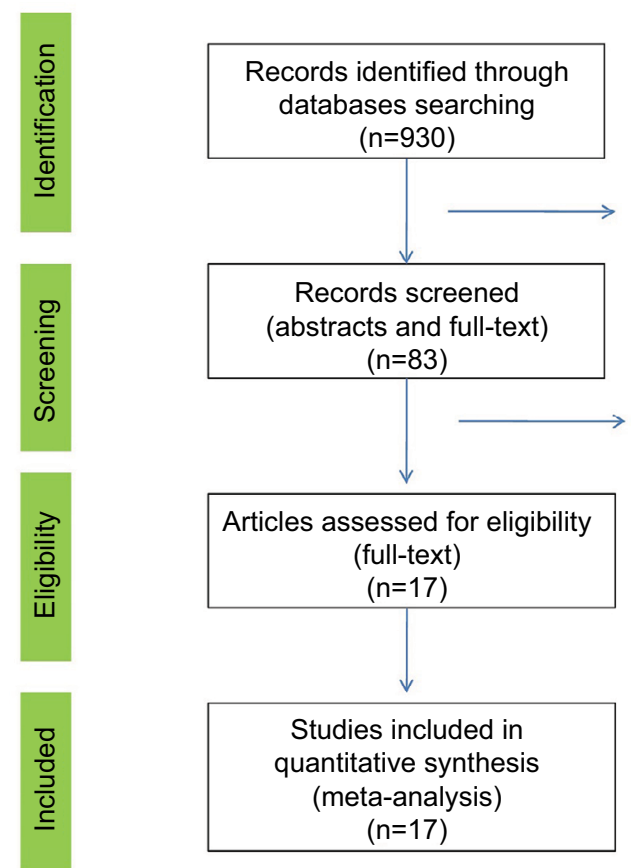

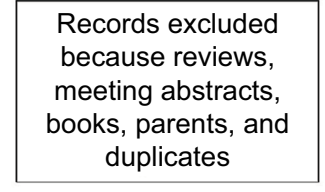

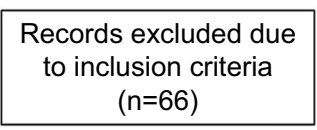

Records excluded due
to inclusion criteria
$(n=66)$

Articles assessed for eligibility (full-text)

(meta-analysis) $(n=17)$

Figure I PRISMA flow chart of the study selection process.

Abbreviation: PRISMA, Preferred Reporting Items for Systematic Reviews and Meta-Analysis.

A

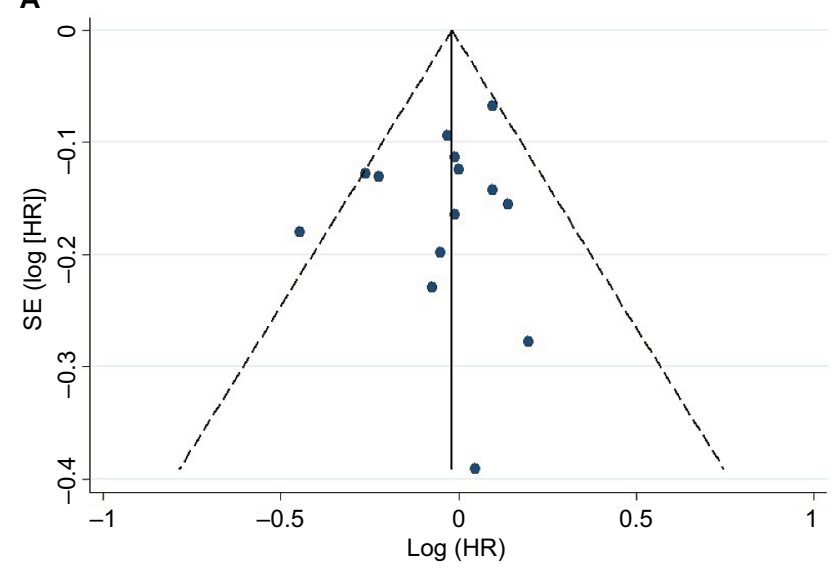

C

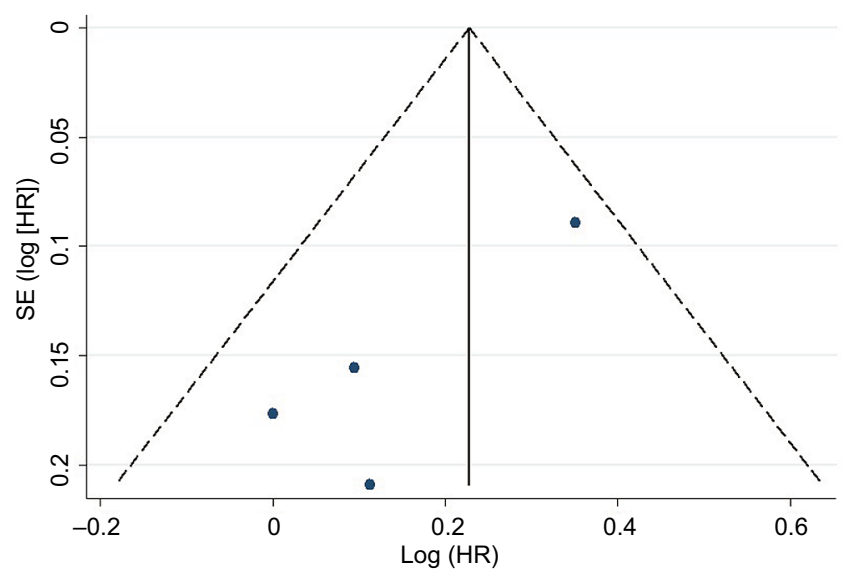

B

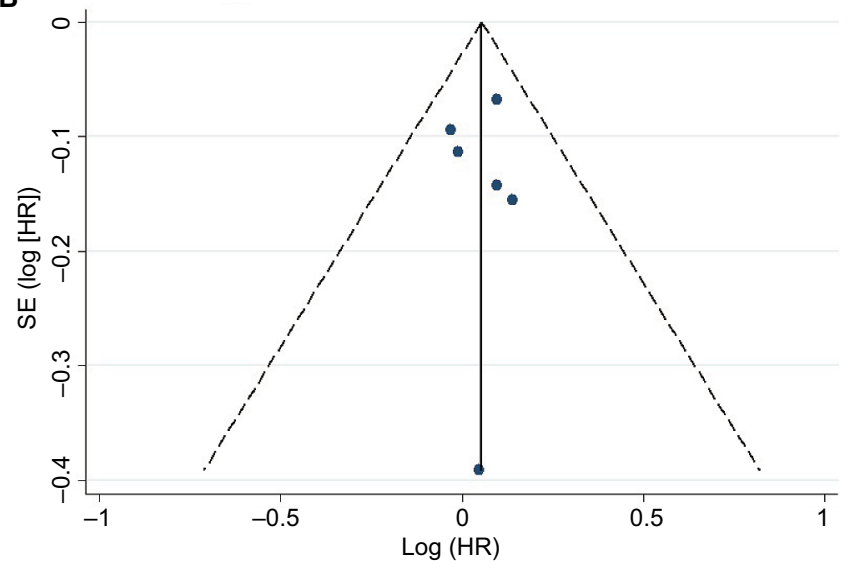

D

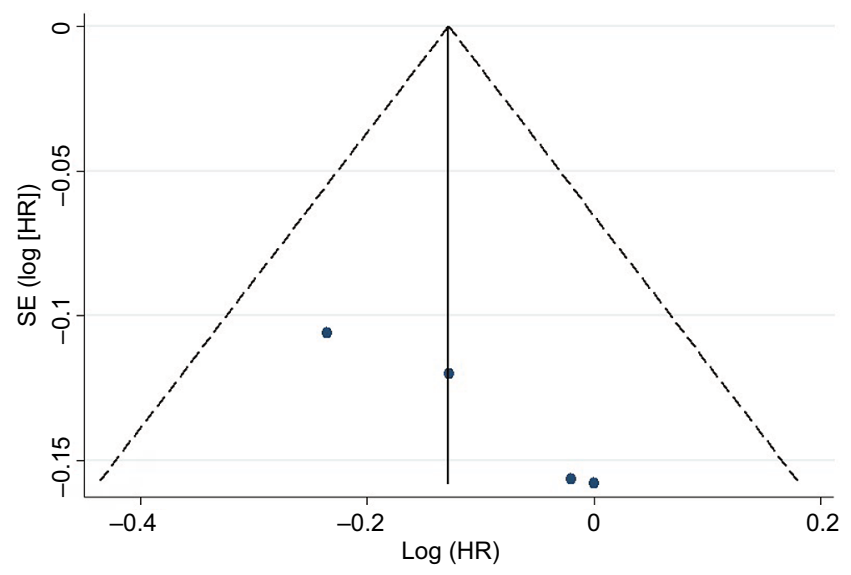

Figure 2 Funnel plots with pseudo $95 \%$ confidence limits for the association between moderate wine intake and the risk of PCa in all the included studies (A), only in cohort-studies (B), association between moderate white wine intake and the risk of $\mathrm{PCa}(\mathbf{C})$, and association between moderate red wine intake and the risk of PCa (D). Abbreviations: PCa, prostate cancer; SE, standard error; HR, hazard ratio. 


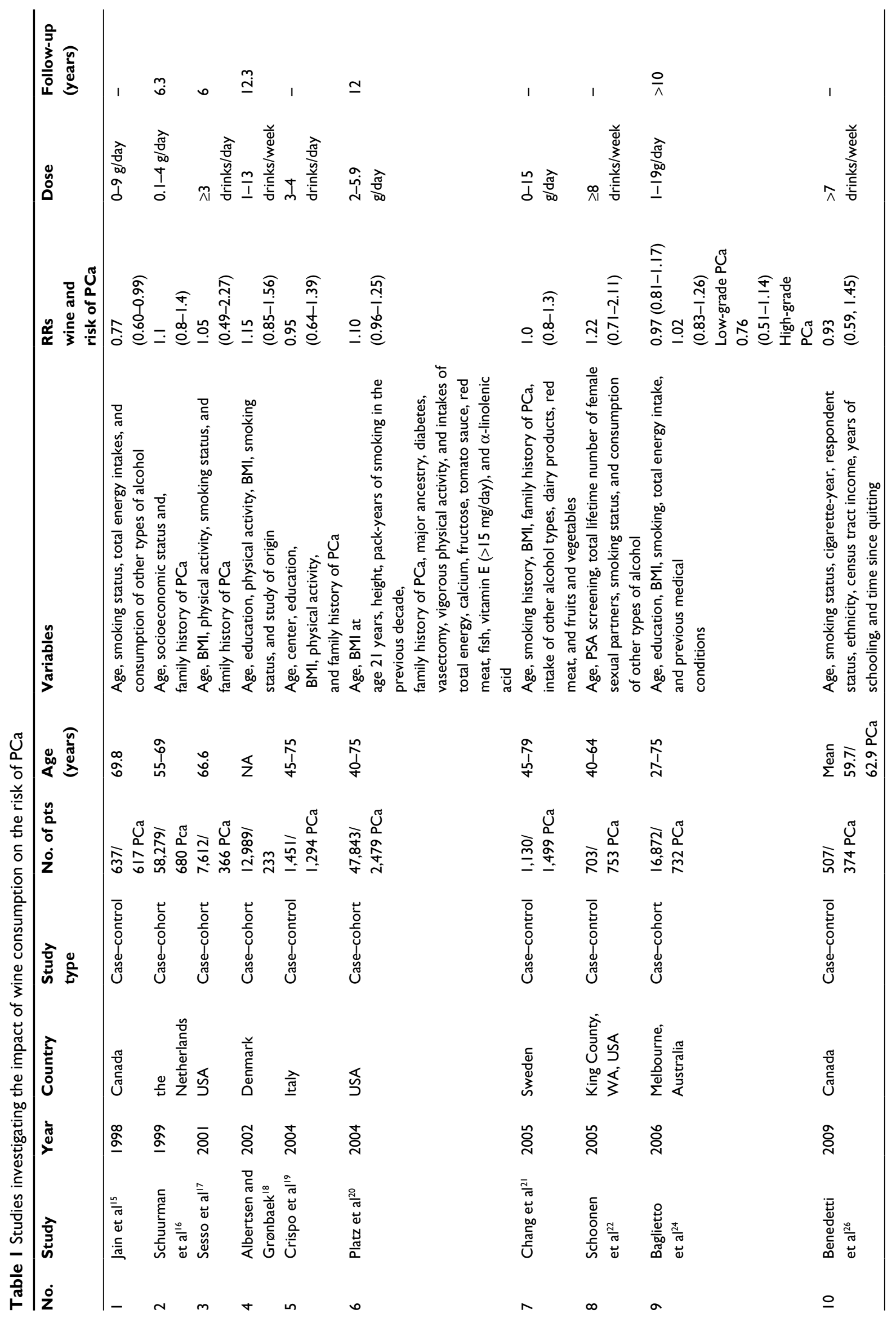




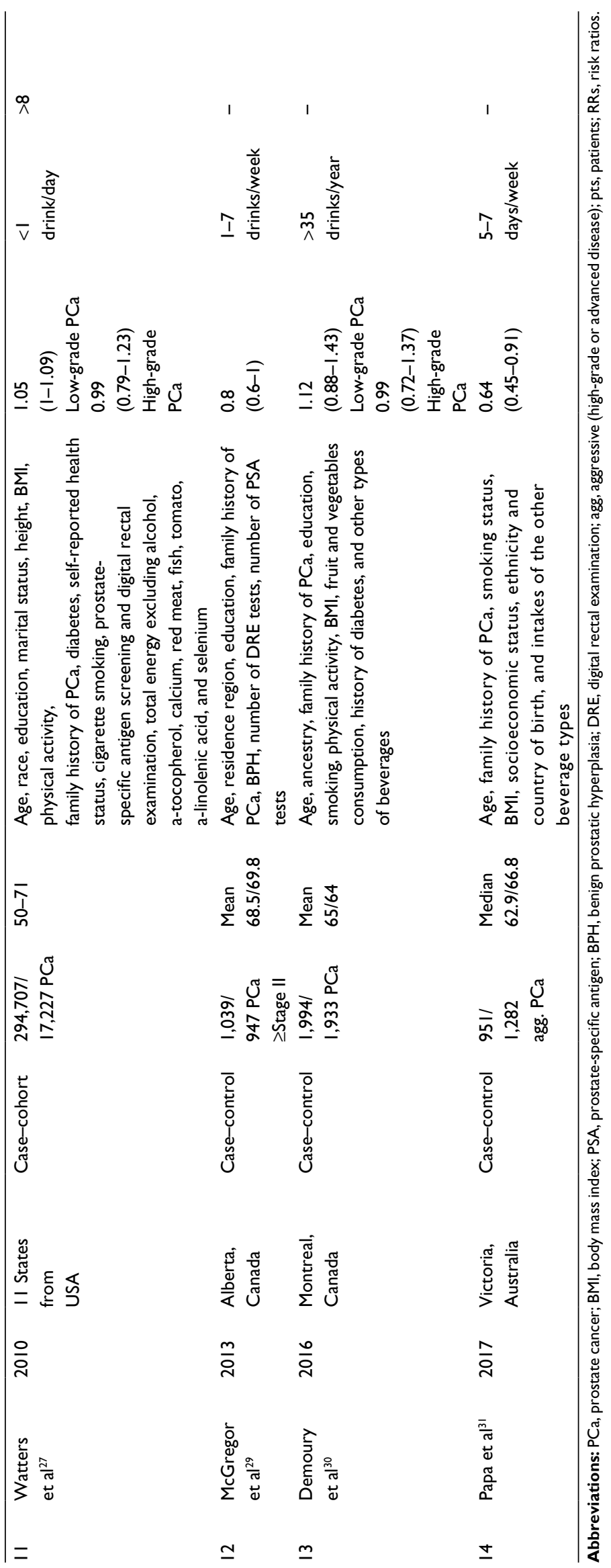


19,238 developed PCa during observation/follow-up). The results were confirmed with a pooled RR of 1.06 (95\% CI $0.96-1.15, p=0.22)$ in the multivariable analysis (Figure 4). The Cochrane's Q test $\left(\chi^{2}=1.9 ; p=0.86\right)$ and $I^{2}$ test $\left(I^{2}=0 \%\right)$ did not show a significant heterogeneity. The funnel plots identified all studies in the pseudo 95\% CI (Figure 2B). The results did not differ when we performed a sensitivity analysis "leave-one-out."

\section{Effect of the type of wine consumed on PCa risk}

Five studies investigated the risk of PCa according to consumption of white or red wine. We used RRs reported for moderate consumption (the same dose for white and red wine was considered). Four were cohort studies $(222,447$ subjects, from which 6,184 developed PCa during observation/follow-up) ${ }^{16,23,25,28}$ and one was a case-control study. ${ }^{22}$

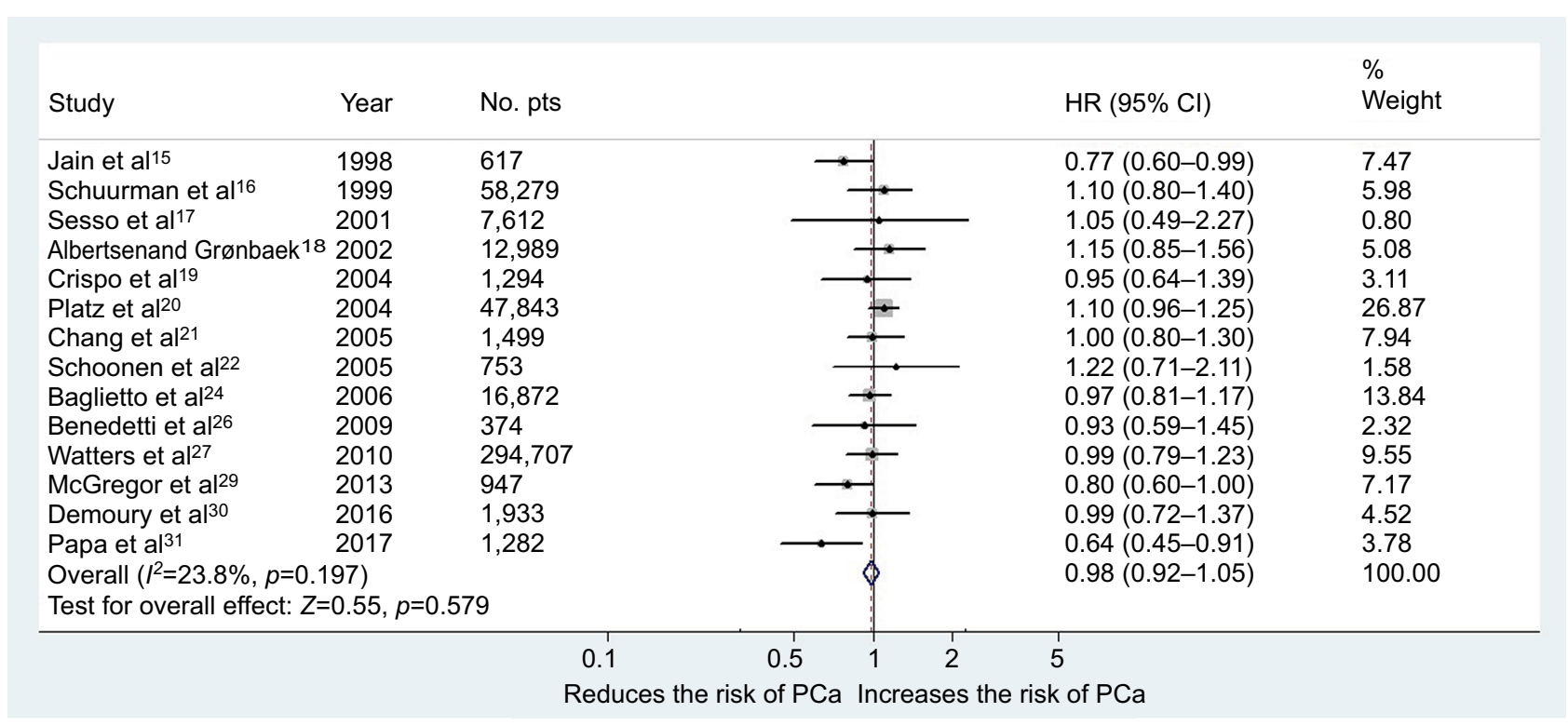

Figure 3 Forest plot for risk of PCa in the case of moderate consumption of wine (all studies).

Abbreviations: PCa, prostate cancer; pts, patients.

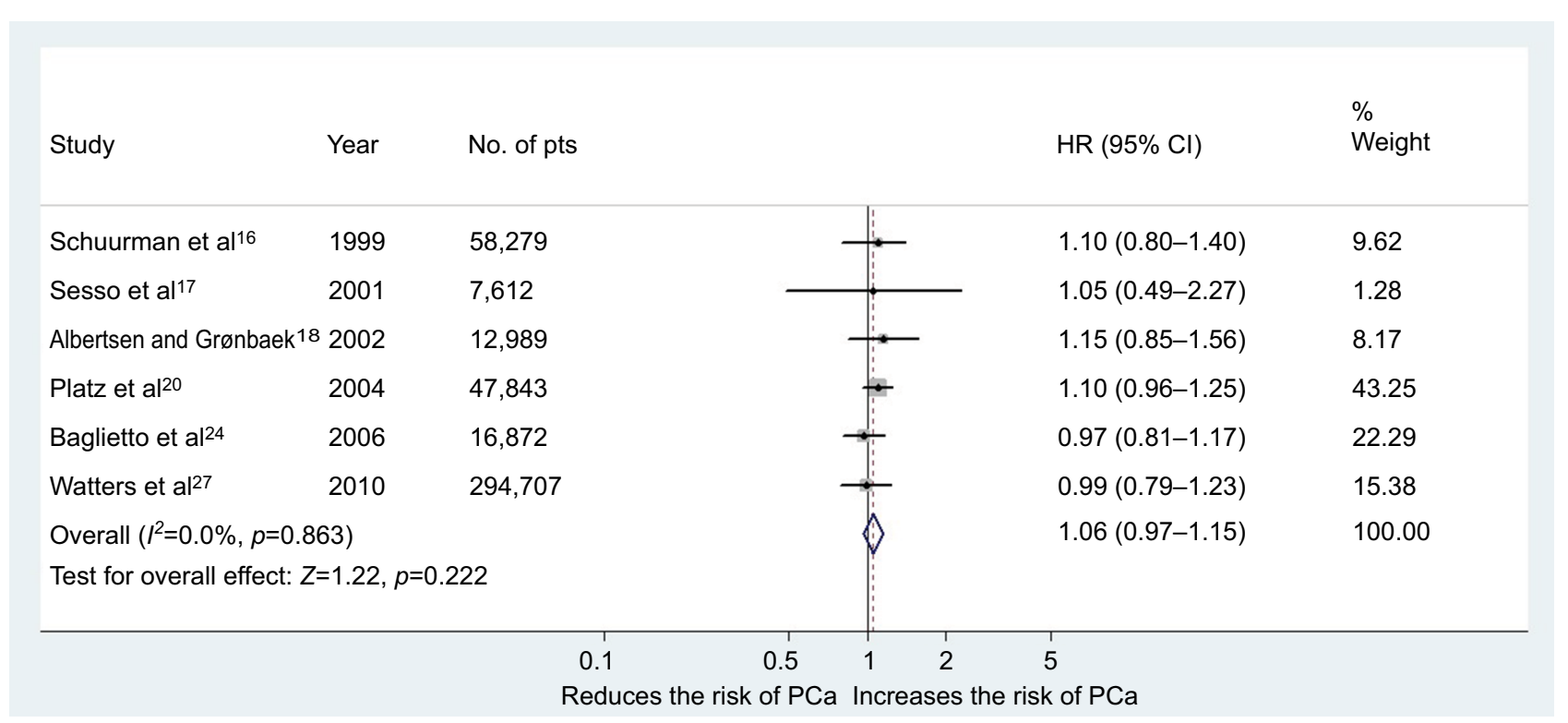

Figure 4 Forest plot for risk of PCa in the case of moderate consumption of wine (cohort studies).

Abbreviations: PCa, prostate cancer; pts, patients. 
The main characteristics of the included studies, as well as dose of wine consumption, are shown in Table 2 for white wine and in Table 3 for red wine. Moderate white wine consumption increased significantly the risk of $\mathrm{PCa}$ with a pooled RR of $1.26(95 \%$ CI 1.10-1.43, $p=0.001)$ in the multivariable analysis (Figure 5). The Cochrane's Q test $\left(\chi^{2}=4.6 ; p=0.2\right)$ and $I^{2}$ test $\left(I^{2}=34.4 \%\right)$ did not show a significant heterogeneity. The funnel plots identified all studies in the pseudo 95\% CI (Figure 2C). When we excluded from the analysis the results reported by Sutcliffe et al, ${ }^{25}$ moderate white wine consumption was not associated with an increased risk of $\mathrm{PCa}$ : pooled RR 1.05 (95\% CI 0.87-1.28, $p=0.56$ ). In all the other cases of exclusion, one study from the analysis showed that white wine was associated with an increased risk of Pca.
Moderate red wine consumption was associated with a decreased risk of PCa with a pooled RR of 0.88 (95\% CI $0.78-0.999, p=0.047$ ) in the multivariable analysis (Figure 6). The Cochrane's Q test $\left(\chi^{2}=2.16 ; p=0.53\right)$ and $I^{2}$ test $\left(I^{2}=0 \%\right)$ did not show a significant heterogeneity. The funnel plots identified all studies in the pseudo 95\% CI (Figure 2D). The results remain significant also after the addition of the RRs from the case-control study of Schoonen et $\mathrm{al}^{22}$ with a pooled RR of 0.86 (95\% CI 0.76-0.97, $p=0.01$ ). However, in this case the heterogeneity increased, but not to a significant level, Cochrane's Q test $\left(\chi^{2}=6.06 ; p=0.19\right)$ and $I^{2}$ test $\left(I^{2}=34 \%\right)$. When we excluded from the analysis the results reported by Sutcliffe et al, ${ }^{25}$ moderate red wine consumption was not associated with a decreased risk of PCa: pooled RR

Table 2 Studies investigating the impact of white wine consumption on the risk of PCa

\begin{tabular}{|c|c|c|c|c|c|c|c|c|c|c|}
\hline No. & Study & Year & Country & $\begin{array}{l}\text { Study } \\
\text { type }\end{array}$ & $\begin{array}{l}\text { No. of } \\
\text { pts }\end{array}$ & $\begin{array}{l}\text { Age } \\
\text { (years) }\end{array}$ & Variables & $\begin{array}{l}\text { RRs white } \\
\text { wine and } \\
\text { risk of } \mathrm{PCa}\end{array}$ & Dose & $\begin{array}{l}\text { Follow-up } \\
\text { (years) }\end{array}$ \\
\hline 1 & $\begin{array}{l}\text { Schuurman } \\
\text { et al }{ }^{16}\end{array}$ & 1999 & $\begin{array}{l}\text { the } \\
\text { Netherlands }\end{array}$ & $\begin{array}{l}\text { Case- } \\
\text { cohort }\end{array}$ & $\begin{array}{l}58,279 / \\
680 \mathrm{Pca}\end{array}$ & $55-69$ & $\begin{array}{l}\text { Age, socioeconomic } \\
\text { status, } \\
\text { family history of PCa }\end{array}$ & $\begin{array}{l}1.0 \\
(0.7-1.4)\end{array}$ & $0.1-4 \mathrm{~g} /$ day & 6.3 \\
\hline 2 & $\begin{array}{l}\text { Schoonen } \\
\text { et } \mathrm{al}^{22}\end{array}$ & 2005 & $\begin{array}{l}\text { King County, } \\
\text { WA, USA }\end{array}$ & $\begin{array}{l}\text { Case- } \\
\text { control }\end{array}$ & $\begin{array}{l}703 / \\
753 \mathrm{PCa}\end{array}$ & $40-64$ & $\begin{array}{l}\text { Age, PSA screening, total } \\
\text { lifetime number of female } \\
\text { sexual partners, smoking } \\
\text { status, and consumption of } \\
\text { other types of alcohol }\end{array}$ & $\begin{array}{l}0.91 \\
(0.44-1.86)\end{array}$ & $\begin{array}{l}\geq 8 \\
\text { drinks/week }\end{array}$ & - \\
\hline 3 & Velicer et $\mathrm{a}^{23}$ & 2006 & $\begin{array}{l}\text { Washington, } \\
\text { USA }\end{array}$ & $\begin{array}{l}\text { Case- } \\
\text { cohort }\end{array}$ & $\begin{array}{l}34,565 / \\
816 \mathrm{PCa}\end{array}$ & $50-76$ & $\begin{array}{l}\text { Age, PSA, other types of } \\
\text { alcohol } \\
\text { consumed }\end{array}$ & $\begin{array}{l}1.12 \\
(0.74-1.68)\end{array}$ & $\begin{array}{l}5 \text { drinks/ } \\
\text { week } \\
\text { to }<2 / \text { day }\end{array}$ & 4 \\
\hline 4 & $\begin{array}{l}\text { Sutcliffe } \\
\text { et } \mathrm{al}^{25}\end{array}$ & 2007 & USA & $\begin{array}{l}\text { Case- } \\
\text { cohort }\end{array}$ & $\begin{array}{l}45,433 / \\
3,348 \mathrm{PCa}\end{array}$ & $40-75$ & $\begin{array}{l}\text { Age, race/ethnicity, BMI, } \\
\text { cumulative family history } \\
\text { of PCa, height, cigarette } \\
\text { smoking in the past I0 years, } \\
\text { baseline intakes of total } \\
\text { energy, tomato sauce, red } \\
\text { meat, fish, calcium } \\
\text { and vitamin E, baseline } \\
\text { energy-adjusted intakes of } \\
\text { fructose and a-linolenic acid, } \\
\text { physical activity and updated } \\
\text { diabetes mellitus type } 2 \\
\text { and vasectomy status, and } \\
\text { all other specific alcoholic } \\
\text { beverage types }\end{array}$ & $\begin{array}{l}1.42 \\
(1.19-1.69)\end{array}$ & $\begin{array}{l}2-4 \\
\text { drinks/week }\end{array}$ & 16 \\
\hline 5 & Chao et $\mathrm{a}^{28}$ & 2010 & $\begin{array}{l}\text { California, } \\
\text { USA }\end{array}$ & $\begin{array}{l}\text { Case- } \\
\text { cohort }\end{array}$ & $\begin{array}{l}84,170 / \\
\mathrm{I}, 340 \mathrm{PCa}\end{array}$ & $45-69$ & $\begin{array}{l}\text { Age, race/ethnicity, } \\
\text { income, BMI, intake of } \\
\text { other alcoholic beverage, } \\
\text { meat consumption, family } \\
\text { history of PCa, person } \\
\text { history of PSA testing, } \\
\text { STI, BPH, BPH surgery, } \\
\text { prostatitis, and diabetes } \\
\text { mellitus }\end{array}$ & $\begin{array}{l}1.10 \\
(0.8 I-1.49)\end{array}$ & $\begin{array}{l}>1 \\
\text { drink/day }\end{array}$ & 5 \\
\hline
\end{tabular}

Abbreviations: PCa, prostate cancer; pts, patients; RRs, risk ratios; BMI, body mass index; PSA, prostate-specific antigen; STIs, sexually transmitted infections; BPH, benign prostatic hyperplasia. 
Table 3 Studies investigating the impact of red wine consumption on the risk of PCa

\begin{tabular}{|c|c|c|c|c|c|c|c|c|c|c|}
\hline No. & Study & Year & Country & $\begin{array}{l}\text { Study } \\
\text { type }\end{array}$ & $\begin{array}{l}\text { No. of } \\
\text { pts }\end{array}$ & $\begin{array}{l}\text { Age } \\
\text { (years) }\end{array}$ & Variables & $\begin{array}{l}\text { RRs } \\
\text { Red wine and } \\
\text { risk of PCa }\end{array}$ & Dose & $\begin{array}{l}\text { Follow-up } \\
\text { (years) }\end{array}$ \\
\hline 1 & $\begin{array}{l}\text { Schuurman } \\
\text { et al }{ }^{16}\end{array}$ & 1999 & $\begin{array}{l}\text { the } \\
\text { Netherlands }\end{array}$ & $\begin{array}{l}\text { Case- } \\
\text { cohort }\end{array}$ & $\begin{array}{l}58,279 / \\
680 \mathrm{PCa}\end{array}$ & $55-69$ & $\begin{array}{l}\text { Age, socioeconomic status, } \\
\text { family history of } \mathrm{PCa}\end{array}$ & $\begin{array}{l}1.0 \\
(0.7-1.3)\end{array}$ & $0.1-4 \mathrm{~g} /$ day & 6.3 \\
\hline 2 & $\begin{array}{l}\text { Schoonen } \\
\text { et } \mathrm{al}^{22}\end{array}$ & 2005 & $\begin{array}{l}\text { King County, } \\
\text { WA, USA }\end{array}$ & $\begin{array}{l}\text { Case- } \\
\text { control }\end{array}$ & $\begin{array}{l}703 / \\
753 \mathrm{PCa}\end{array}$ & $40-64$ & $\begin{array}{l}\text { Age, PSA screening, total } \\
\text { lifetime number of female } \\
\text { sexual partners, smoking status, } \\
\text { and consumption of other types } \\
\text { of alcohol }\end{array}$ & $\begin{array}{l}0.45 \\
(0.23-0.85)\end{array}$ & $\begin{array}{l}\geq 8 \\
\text { drinks/ } \\
\text { week }\end{array}$ & - \\
\hline 3 & $\begin{array}{l}\text { Velicer } \\
\text { et } \mathrm{a}^{23}\end{array}$ & 2006 & $\begin{array}{l}\text { Washington, } \\
\text { USA }\end{array}$ & $\begin{array}{l}\text { Case- } \\
\text { cohort }\end{array}$ & $\begin{array}{l}34,565 / \\
816 \mathrm{PCa}\end{array}$ & $50-76$ & $\begin{array}{l}\text { Age, PSA, other types of } \\
\text { alcohol } \\
\text { consumed }\end{array}$ & $\begin{array}{l}0.98 \\
(0.72-1.33)\end{array}$ & $\begin{array}{l}5 \text { drinks/ } \\
\text { week } \\
\text { to }<2 / \text { day }\end{array}$ & 4 \\
\hline 4 & $\begin{array}{l}\text { Sutcliffe } \\
\text { et } \mathrm{a}^{25}\end{array}$ & 2007 & USA & $\begin{array}{l}\text { Case- } \\
\text { cohort }\end{array}$ & $\begin{array}{l}45,433 / \\
3,348 \mathrm{PCa}\end{array}$ & $40-75$ & $\begin{array}{l}\text { Age, race/ethnicity, BMI, } \\
\text { cumulative family history of } \\
\text { PCa, height, cigarette smoking } \\
\text { in the past } 10 \text { years, baseline } \\
\text { intakes of total energy, tomato } \\
\text { sauce, red meat, fish, calcium } \\
\text { and vitamin E, baseline energy- } \\
\text { adjusted intakes of fructose and } \\
\text { a-linolenic acid, physical activity } \\
\text { and updated diabetes mellitus } \\
\text { type } 2 \text { and vasectomy status, } \\
\text { and all other specific alcoholic } \\
\text { beverage types }\end{array}$ & $\begin{array}{l}0.79 \\
(0.64-0.97)\end{array}$ & $\begin{array}{l}2-4 \\
\text { drinks/ } \\
\text { week }\end{array}$ & 16 \\
\hline 5 & $\begin{array}{l}\text { Chao } \\
\text { et } \mathrm{al}^{28}\end{array}$ & 2010 & $\begin{array}{l}\text { California, } \\
\text { USA }\end{array}$ & $\begin{array}{l}\text { Case- } \\
\text { cohort }\end{array}$ & $\begin{array}{l}84,170 / \\
\mathrm{I}, 340 \mathrm{PCa}\end{array}$ & $45-69$ & $\begin{array}{l}\text { Age, race/ethnicity, income, } \\
\text { BMI, intake of other alcoholic } \\
\text { beverage, meat consumption, } \\
\text { family history of PCa, person } \\
\text { history of PSA testing, STI, } \\
\text { BPH, BPH surgery, prostatitis, } \\
\text { and diabetes mellitus }\end{array}$ & $\begin{array}{l}0.88 \\
(0.70-1.12)\end{array}$ & $\begin{array}{l}>1 \\
\text { drink/day }\end{array}$ & 5 \\
\hline
\end{tabular}

Abbreviations: PCa, prostate cancer; pts, patients; RRs, risk ratios; BMI, body mass index; PSA, prostate specific antigen; BPH, benign prostatic hyperplasia; STIs, sexually transmitted infections.

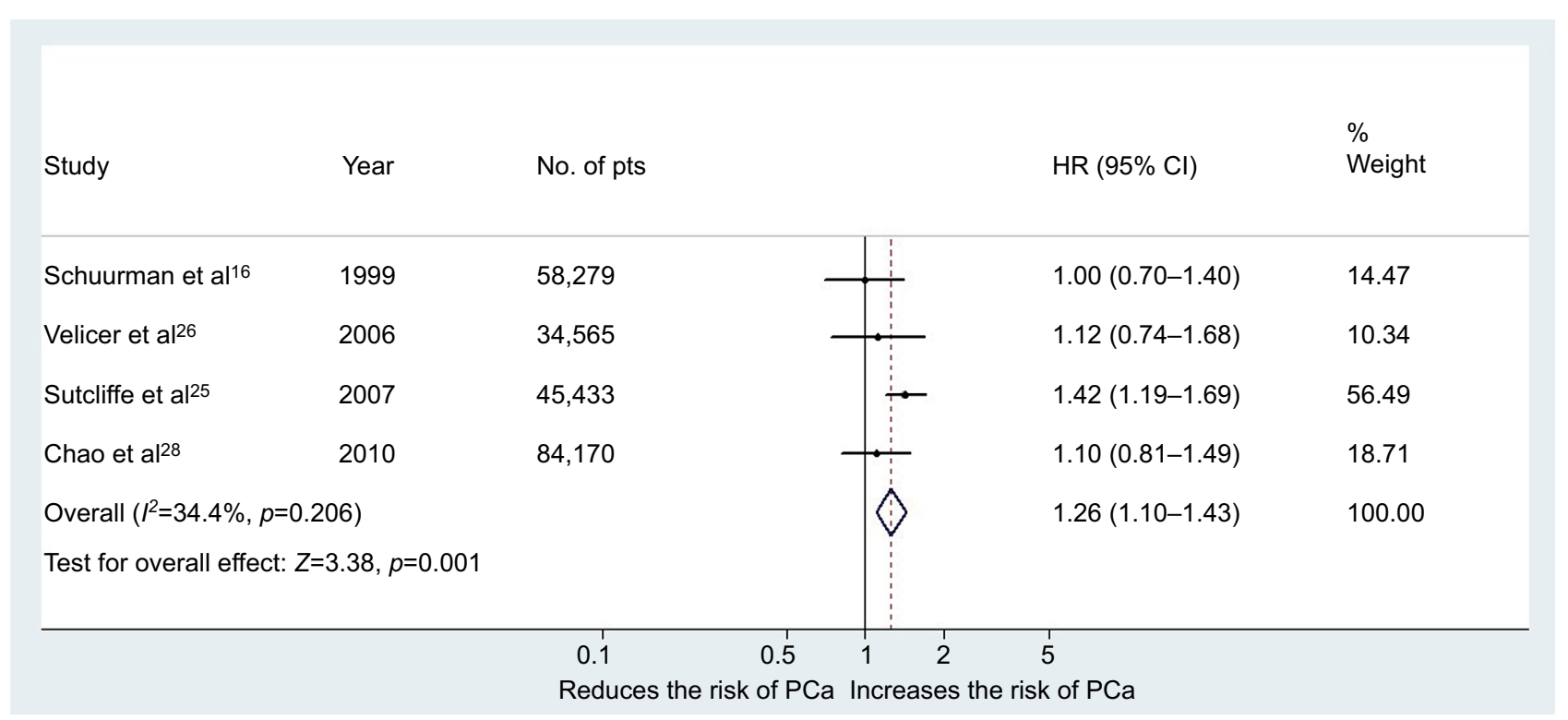

Figure 5 Forest plot for the risk of PCa in the case of moderate consumption of white wine (cohort studies).

Abbreviations: PCa, prostate cancer; pts, patients. 


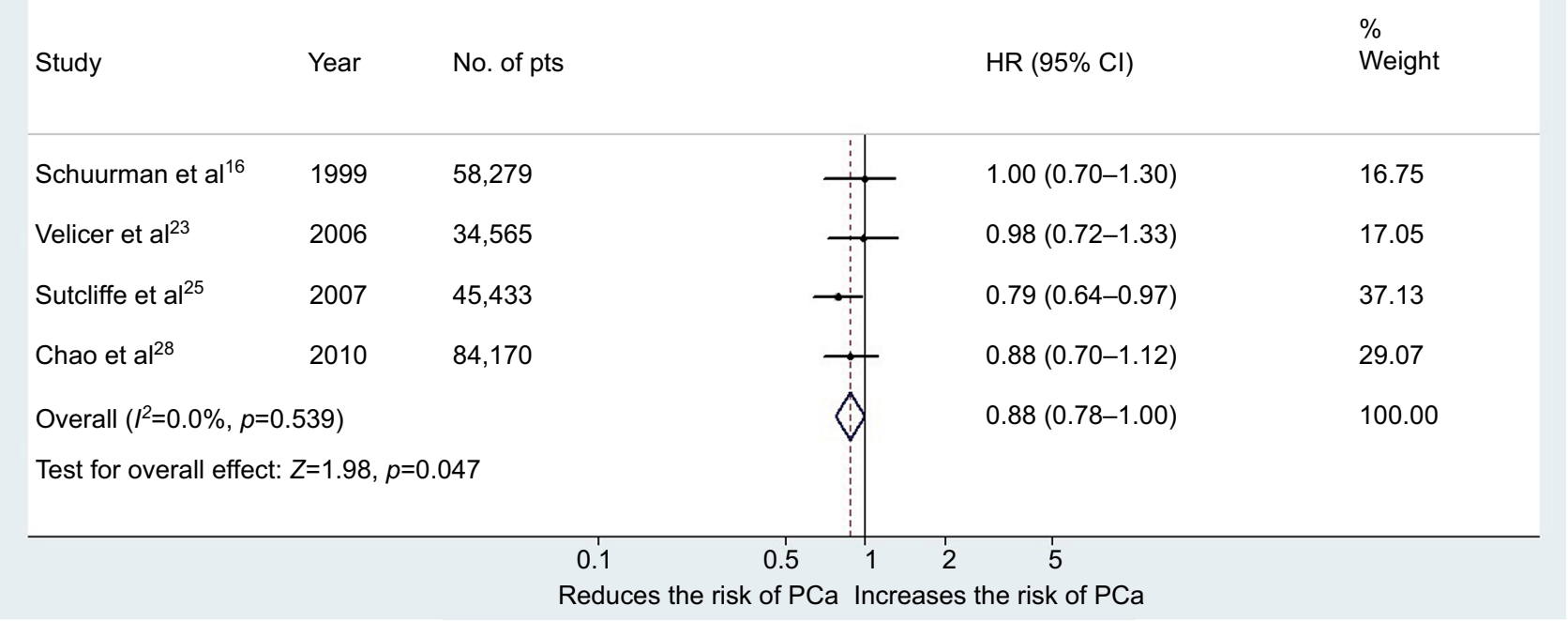

Figure 6 Forest plot for risk of PCa in the case of moderate consumption of red wine (cohort studies).

Abbreviations: $\mathrm{PCa}$, prostate cancer; pts, patients.

$0.88(95 \%$ CI $0.71-1.09, p=0.24)$. In all the other cases of exclusion, only one study from the analysis showed that red wine was associated with a decreased risk of Pca.

\section{Discussion}

This study is to our knowledge the first meta-analysis to investigate the impact of moderate wine consumption and the risk of developing PCa, including 611,169 subjects from 17 studies. According to this meta-analysis moderate wine consumption is not a risk factor for $\mathrm{PCa}$ development. Interestingly, the analysis regarding type of wine consumed sustains the fact that moderate wine consumption does not impact PCa risk. We found an antagonist effect as moderate white wine consumption increases the risk of $\mathrm{PCa}$, whereas moderate red wine consumption had a protective role against PCa. However, when we excluded the results reported by Sutcliffe et $\mathrm{al}^{25}$ (45,433 subjects with 16 years follow-up), there was not a significant association between type of wine consumed and risk of $\mathrm{PCa}$.

Nevertheless, our meta-analysis has several limitations. First, there is a selection bias in the studies as all were nonrandomized observational or case-control studies. Second, the definition of moderate consumption is imprecise with differences between studies introducing heterogeneous results. Still, all studies had a maximum of one glass of wine per day as moderate consumption. Third, despite a large number of patients in our analyses, the number of studies in our meta-analysis was limited to 17 . Fourth, most studies were done in western countries with a likely preponderance of Caucasians. Metabolization and polymorphisms are highly variable between races and habits. Fifth, we decided to restrict the present meta-analysis to "moderate consumption" of wine alone, thus precluding analyses of dose-response relationship. We analyzed only the effect of moderate consumption; as in many countries, there are dietary habits that include one glass of wine per day during meals and the scope of the meta-analysis was not to encourage alcohol/wine consumption, but instead to point out the effects of responsible wine drinking on the risk of PCa.

The relationship between alcohol consumption and the risk of PCa remains a controversial issue. ${ }^{32}$ Middleton Fillmore et al demonstrated in a meta-analysis that heavy alcohol consumption is associated with a higher risk of developing $\mathrm{PCa} .{ }^{33}$ Similarly, Zhao et al's meta-analysis showed a significant dose-response relationship between level of alcohol intake and risk of $\mathrm{PCa} .{ }^{9} \mathrm{On}$ the contrary, a large prospective European study that included 142,607 male participants found no association between alcohol consumption and PCa risk. ${ }^{10}$ Regarding types of alcohol consumption, in a large cohort of 3,927 subjects, Demoury et al showed that beer was associated with a $37 \%$ increase risk of highgrade $\mathrm{PCa} .{ }^{30}$ In the present study, we found that wine is not associated with an increased risk of PCa as other alcohol or beer consumption is. This could be based on several factors that make wine less harmful than other types of alcohols. One of the factors might be the chemical composition of wine, which is a hydroalcoholic solution ( $78 \%$ water) with a wide range of bioactive chemical components, including 
aldehydes, esters, ketones, lipids, minerals, organic acids, phenolics, soluble proteins, sugars, and vitamins. ${ }^{34}$ Second, the anticarcinogenic effect of polyphenols mainly contained by red wine may balance any other harmful effects of wine consumption. ${ }^{35}$ Third, in the case of beer, the bioavailability of the phenolic compounds is very low, thus decreasing their potential anticarcinogenic effects. ${ }^{36}$

Furthermore, the mechanism between alcohol consumption and carcinogenesis is not fully understood. It seems to be based on acetaldehyde, the first metabolite of ethanol that has been suggested to be carcinogenic by promoting cancer development though various mechanisms, such as interference with DNA replication, induction of DNA damage, and formation of DNA adducts. ${ }^{37}$ However, wine consumption, especially red wine, has been associated with decreased inflammation and overall mortality as well as moderate alcohol consumption. ${ }^{10,38}$ Schoonen et $\mathrm{al}^{22}$ and Sutcliffe et $\mathrm{al}^{25}$ found, in large cohort studies, that red wine consumption decreases the risk of $\mathrm{PCa}$, whereas white wine does not. Red wine's protective role against $\mathrm{PCa}$ development could be due to the bioactivity of polyphenols that are a complex mixture of flavonoids (such as anthocyanins and flavan-3-ols) and nonflavonoids (such as resveratrol, cinnamates, and gallic acid). Resveratrol is the most studied compound and its concentration is 10 -fold higher than in white wine. ${ }^{39}$ Resveratrol is added from the skin of red grapes during the creation process. Its concentration in red wine ranges from 1.2 to $2.0 \mathrm{~g} / \mathrm{L} .{ }^{39}$ It has been studied regarding its anticarcinogenesis including $\mathrm{PCa}$, and many studies showed that resveratrol causes cell growth, proliferation inhibition, and activation of apoptosis in human PCa cell lines including PC3, DU145, and $\mathrm{LNCaP}^{40-43}$ Sgambato et al found that resveratrol not only inhibits cell proliferation but also prevents the accumulation of reactive oxygen species production and oxidative DNA damage in cells exposed to oxidative agents. ${ }^{44}$ On the other hand, white wine contains also a small amount of resveratrol, but despite an experimental study that showed an association between white wine and antiproliferative effect, clinical studies do not support this finding. ${ }^{43}$ Nevertheless, the beneficial effects of moderate red wine consumption might be due to all its compounds and not only due to resveratrol. ${ }^{39}$ Although we focused only on "moderate" consumption of red wine in this study, it is unclear whether effectiveness of red wine polyphenols depends on the amount of consumption or not. To better assess the relationship between wine consumption, especially the appropriate amount of red wine and PCa risk in the general population, further studies are needed.

\section{Conclusion}

In this meta-analysis, moderate wine consumption did not influence the risk of PCa. However, moderate consumption of white wine increased the risk of $\mathrm{PCa}$, whereas moderate consumption of red wine had a protective role. This hypothesis-generating data should serve as a rationale for uncovering the molecular underpinnings of this differential effect in order to potentially devise prevention strategies in the at-risk population.

\section{Acknowledgments}

MDV had an EUSP (European Urological Scholarship Programme) lab/clinical fellowship awarded by EAU (European Association of Urology) and an Ernst Mach Grant awarded by OeAD, Austria.

\section{Author Contributions}

All authors contributed towards data analysis, drafting and critically revising the paper and agree to be accountable for all aspects of the work.

\section{Disclosure}

The authors report no conflicts of interest in this work.

\section{References}

1. Siegel RL, Miller KD, Jemal A. Cancer statistics, 2017. CA Cancer J Clin. 2017;67(1):7-30.

2. Center MM, Jemal A, Lortet-Tieulent J, et al. International variation in prostate cancer incidence and mortality rates. Eur Urol. 2012;61(6):1079-1092.

3. Ferlay J, Soerjomataram I, Dikshit R, et al. Cancer incidence and mortality worldwide: sources, methods and major patterns in GLOBOCAN 2012. Int J Cancer. 2015;136(5):E359-E386.

4. Lynch HT, Kosoko-Lasaki O, Leslie SW, et al. Screening for familial and hereditary prostate cancer. Int J Cancer. 2016;138(11):2579-2591.

5. Randazzo M, Müller A, Carlsson S, et al. A positive family history as a risk factor for prostate cancer in a population-based study with organised prostate-specific antigen screening: results of the Swiss European Randomised Study of Screening for Prostate Cancer (ERSPC, Aarau). BJU Int. 2016;117(4):576-583.

6. Eeles RA, Olama AAA, Benlloch S, et al. Identification of 23 new prostate cancer susceptibility loci using the iCOGS custom genotyping array. Nat Genet. 2013;45(4):385-391, 391e1-e2.

7. Tan DSW, Mok TSK, Rebbeck TR. Cancer genomics: diversity and disparity across ethnicity and geography. J Clin Oncol.2016;34(1):91-101.

8. Mottet N, Bellmunt J, Bolla M, et al. EAU-ESTRO-SIOG Guidelines on Prostate Cancer. Part 1: screening, diagnosis, and local treatment with curative intent. Eur Urol. 2017;71(4):618-629.

9. Zhao J, Stockwell T, Roemer A, Chikritzhs T. Is alcohol consumption a risk factor for prostate cancer? A systematic review and meta-analysis. BMC Cancer. 2016;16(1):845.

10. Rohrmann S, Linseisen J, Key TJ, et al. Alcohol consumption and the risk for prostate cancer in the European Prospective Investigation into Cancer and Nutrition. Cancer Epidemiol Biomark Prev. 2008;17(5): $1282-1287$. 
11. Aziz MH, Kumar R, Ahmad N. Cancer chemoprevention by resveratrol: in vitro and in vivo studies and the underlying mechanisms (review). Int J Oncol. 2003;23(1):17-28.

12. Jasiński M, Jasińska L, Ogrodowczyk M. Resveratrol in prostate diseases: a short review. Cent Eur J Urol. 2013;66(2):144-149.

13. Moher D, Liberati A, Tetzlaff J, Altman DG, PRISMA Group. Preferred reporting items for systematic reviews and meta-analyses: the PRISMA statement. Int J Surg. 2010;8(5):336-341.

14. Wells GA, Shea B, O'Connell D, et al. The Newcastle-Ottawa Scale (NOS) for assessing the quality if nonrandomised studies in metaanalyses. Available from: http://www.Ohri.ca/Programs/Clinical_epidemiology/Oxford.Htm. Accessed October 30, 2017.

15. Jain MG, Hislop GT, Howe GR, Burch JD, Ghadirian P. Alcohol and other beverage use and prostate cancer risk among Canadian men. Int J Cancer. 1998;78(6):707-711.

16. Schuurman AG, Goldbohm RA, van den Brandt PA. A prospective cohort study on consumption of alcoholic beverages in relation to prostate cancer incidence (The Netherlands). Cancer Causes Control. 1999;10(6):597-605.

17. Sesso HD, Paffenbarger RS, Lee IM. Alcohol consumption and risk of prostate cancer: The Harvard Alumni Health Study. Int J Epidemiol. 2001;30(4):749-755.

18. Albertsen K, Grønbaek M. Does amount or type of alcohol influence the risk of prostate cancer? Prostate. 2002;52(4):297-304.

19. Crispo A, Talamini R, Gallus S, et al. Alcohol and the risk of prostate cancer and benign prostatic hyperplasia. Urology. 2004;64(4):717-722.

20. Platz EA, Leitzmann MF, Rimm EB, Willett WC, Giovannucci E. Alcohol intake, drinking patterns, and risk of prostate cancer in a large prospective cohort study. Am J Epidemiol. 2004;159(5):444-453.

21. Chang ET, Hedelin M, Adami H-O, Grönberg H, Bälter KA. Alcohol drinking and risk of localized versus advanced and sporadic versus familial prostate cancer in Sweden. Cancer Causes Control. 2005;16(3):275-284.

22. Schoonen WM, Salinas CA, Kiemeney LALM, Stanford JL. Alcohol consumption and risk of prostate cancer in middle-aged men. Int $J$ Cancer. 2005;113(1):133-140.

23. Velicer CM, Kristal A, White E. Alcohol use and the risk of prostate cancer: results from the VITAL cohort study. Nutr Cancer. 2006;56(1):50-56.

24. Baglietto L, Severi G, English DR, Hopper JL, Giles GG. Alcohol consumption and prostate cancer risk: results from the Melbourne collaborative cohort study. Int J Cancer. 2006;119(6):1501-1504.

25. Sutcliffe S, Giovannucci E, Leitzmann MF, et al. A prospective cohort study of red wine consumption and risk of prostate cancer. Int J Cancer. 2007;120(7):1529-1535.

26. Benedetti A, Parent M-E, Siemiatycki J. Lifetime consumption of alcoholic beverages and risk of 13 types of cancer in men: results from a casecontrol study in Montreal. Cancer Detect Prev. 2009;32(5-6):352-362.

27. Watters JL, Park Y, Hollenbeck A, Schatzkin A, Albanes D. Alcoholic beverages and prostate cancer in a prospective US cohort study. Am J Epidemiol. 2010;172(7):773-780.
28. Chao C, Haque R, Van Den Eeden SK, Caan BJ, Poon K-YT, Quinn VP. Red wine consumption and risk of prostate cancer: the California Men's Health Study. Int J Cancer. 2010;126(1):171-179.

29. McGregor SE, Courneya KS, Kopciuk KA, Tosevski C, Friedenreich CM. Case-control study of lifetime alcohol intake and prostate cancer risk. Cancer Causes Control. 2013;24(3):451-461.

30. Demoury C, Karakiewicz P, Parent M-E. Association between lifetime alcohol consumption and prostate cancer risk: a case-control study in Montreal, Canada. Cancer Epidemiol. 2016;45:11-17.

31. Papa NP, MacInnis RJ, Jayasekara H, et al. Total and beverage-specific alcohol intake and the risk of aggressive prostate cancer: a case-control study. Prostate Cancer Prostatic Dis. 2017;20(3):305-310.

32. Fowke JH, Howard L, Andriole GL, Freedland SJ. Alcohol intake increases high-grade prostate cancer risk among men taking dutasteride in the REDUCE trial. Eur Urol. 2014;66(6):1133-1138.

33. Middleton Fillmore K, Chikritzhs T, Stockwell T, Bostrom A, Pascal R. Alcohol use and prostate cancer: a meta-analysis. Mol Nutr Food Res. 2009;53(2):240-255.

34. Fernandes I, Pérez-Gregorio R, Soares S, Mateus N, de Freitas V. Wine flavonoids in health and disease prevention. Molecules. 2017;22(2):pii, E292.

35. Sancho M, Mach N. [Effects of wine polyphenols on cancer prevention]. Nutr Hosp. 2014;31(2):535-551. Spanish.

36. Grønbaek M, Mortensen EL, Mygind K, et al. Beer, wine, spirits and subjective health. J Epidemiol Community Health. 1999;53(11):721-724.

37. Seitz HK, Becker P. Alcohol metabolism and cancer risk. Alcohol Res Health J. 2007;30(1):38-41, 44-47.

38. Holman CD, English DR, Milne E, Winter MG. Meta-analysis of alcohol and all-cause mortality: a validation of NHMRC recommendations. Med J Aust. 1996;164(3):141-145.

39. Arranz S, Chiva-Blanch G, Valderas-Martínez P, Medina-Remón A, Lamuela-Raventós RM, Estruch R. Wine, beer, alcohol and polyphenols on cardiovascular disease and cancer. Nutrients. 2012;4(7):759-781.

40. Kampa M, Hatzoglou A, Notas G, et al. Wine antioxidant polyphenols inhibit the proliferation of human prostate cancer cell lines. Nutr Cancer. 2000;37(2):223-233.

41. Brizuela L, Dayon A, Doumerc N, et al. The sphingosine kinase-1 survival pathway is a molecular target for the tumor-suppressive tea and wine polyphenols in prostate cancer. FASEB J. 2010;24(10): 3882-3894.

42. Burton LJ, Rivera M, Hawsawi O, et al. Muscadine grape skin extract induces an unfolded protein response-mediated autophagy in prostate cancer cells: a TMT-based quantitative proteomic analysis. PloS One. 2016;11(10):e016411.

43. Tenta R, Fragopoulou E, Tsoukala M, et al. Antiproliferative effects of red and white wine extracts in PC-3 prostate cancer cells. Nutr Cancer. 2017;69(6):952-961.

44. Sgambato A, Ardito R, Faraglia B, Boninsegna A, Wolf FI, Cittadini A. Resveratrol, a natural phenolic compound, inhibits cell proliferation and prevents oxidative DNA damage. Mutat Res. 2001;496(1-2):171-180. 


\section{Supplementary materials}

\begin{tabular}{|c|c|c|c|c|c|c|c|c|}
\hline Study and year & \multicolumn{3}{|c|}{ Selection } & \multicolumn{2}{|c|}{ Comparability } & \multicolumn{3}{|c|}{ Exposure } \\
\hline Jain et al, 1998 ' & $\star$ & $\star$ & $\star$ & & $\star$ & $\star$ & $\star$ & \\
\hline Schuurman et al, $1999^{2}$ & $\star$ & $\star$ & & & $\star$ & $\star$ & $\star$ & \\
\hline Sesso et al, $200 \mathrm{I}^{3}$ & $\star$ & $\star$ & $\star$ & $\star$ & $\star$ & $\star$ & $\star$ & \\
\hline Albertsen and Grønbaek, $2002^{4}$ & $\star$ & $\star$ & & $\star$ & $\star$ & $\star$ & $\star$ & \\
\hline Crispo et al, $2004^{5}$ & $\star$ & $\star$ & & & $\star$ & $\star$ & & $\star$ \\
\hline Platz et al, $2004^{6}$ & $\star$ & t & & & $\star$ & $\star$ & $\star$ & \\
\hline Chang et al, $2005^{7}$ & $\star$ & $\star$ & $\star$ & $\star$ & $\star$ & $\star$ & $\star$ & \\
\hline Schoonen et al, $2005^{8}$ & $\star$ & $\star$ & $\star$ & & $\star$ & $\star$ & & $\star$ \\
\hline Baglietto et al, $2006^{9}$ & $\star$ & t & & $\star$ & & & & $\star$ \\
\hline Benedetti et al, $2009^{10}$ & $\star$ & $\star$ & $\star$ & & $\star$ & & $\star$ & \\
\hline Watters et al, 2010"1 & $\star$ & t & $\star$ & & $\star$ & $\star$ & $\star$ & \\
\hline McGregor et.al, $2013^{12}$ & $\star$ & $\star$ & $\star$ & & $\star$ & $\star$ & $\star$ & \\
\hline Demoury et al, $2016^{13}$ & $\star$ & t & & & $\star$ & $\star$ & $x$ & \\
\hline Papa et al, $2017^{14}$ & $\star$ & $\star$ & & & $\star$ & & $x$ & \\
\hline Velicer et al, $2006^{15}$ & $\star$ & 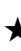 & $\star$ & & $\star$ & & $x$ & \\
\hline Sutcliffe et al, $2007^{16}$ & $\star$ & $x$ & & & $\star$ & & $x$ & \\
\hline Chao et al, $2010^{17}$ & & $\star$ & $\star$ & & $\star$ & & 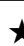 & \\
\hline
\end{tabular}

Figure SI Newcastle-Ottawa Scale.

Notes: Each study was judged on eight items, categorized into three groups: the selection of the study groups; the comparability of the groups; and the ascertainment of the exposure of interest for cohort studies. There was a maximum of 4 stars for the selection, 2 stars for the comparability, and 3 stars for exposure components. The highest quality studies are awarded up to 9 stars. 
A

\begin{tabular}{|c|c|c|c|c|c|c|c|c|c|c|c|c|c|}
\hline & 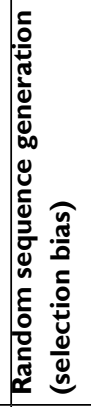 & 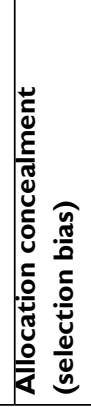 & 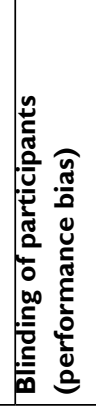 & 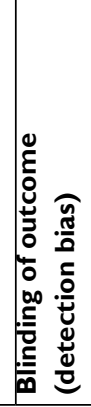 & 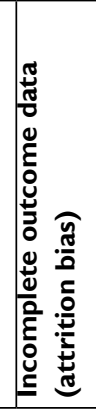 & 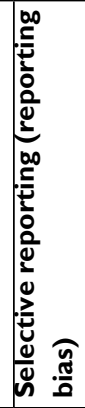 & ô & 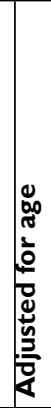 & 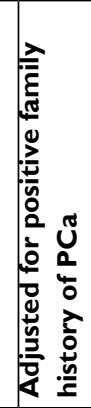 & 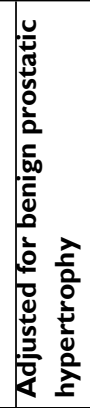 & 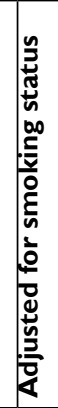 & 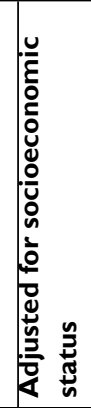 & 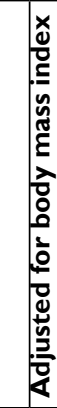 \\
\hline Study and year & \multicolumn{7}{|c|}{ Assessment of the main biases } & \multicolumn{6}{|c|}{ Analysis of PCa risk } \\
\hline Jain et al, 19981 & & & & & & & 7 & & & & & & \\
\hline Schuurman et al, $1999^{2}$ & & & & & & & 6 & & & & & & \\
\hline Sesso et al, $200 I^{3}$ & & & & & & & 7 & & & & & & \\
\hline Albertsen and Grønbaek, $2002^{4}$ & & & & & & & 6 & & & & & & \\
\hline Crispo et al, $2004^{5}$ & & & & & & & 7 & & & & & & \\
\hline Platz et al, $2004^{6}$ & & & & & & & 6 & & & & & & \\
\hline Chang et al, $2005^{7}$ & & & & & & & 7 & & & & & & \\
\hline Schoonen et al, $2005^{8}$ & & & & & & & 8 & & & & & & \\
\hline Baglietto et al, $2006^{9}$ & & & & & & & 6 & & & & & & \\
\hline Benedetti et al, $2009^{10}$ & & & & & & & 7 & & & & & & \\
\hline Watters et al, 2010"1 & & & & & & & 8 & & & & & & \\
\hline McGregor et al, $2013^{12}$ & & & & & & & 7 & & & & & & \\
\hline Demoury et al, $2016^{13}$ & & & & & & & 6 & & & & & & \\
\hline Papa et al, $2017^{14}$ & & & & & & & 6 & & & & & & \\
\hline
\end{tabular}

B

\begin{tabular}{|c|c|c|c|c|c|c|c|c|c|c|c|c|c|}
\hline & 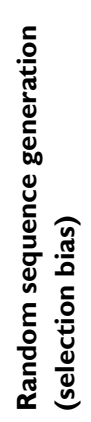 & 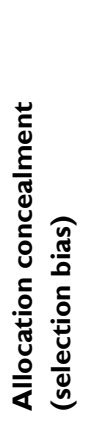 & 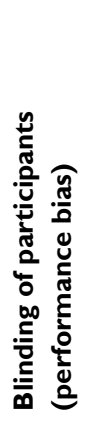 & 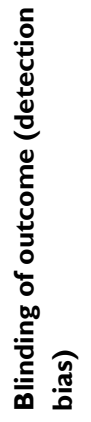 & 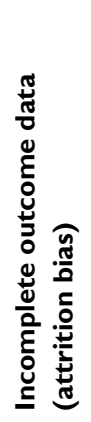 & 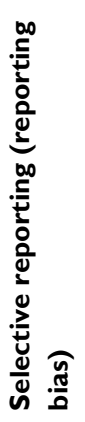 & $\begin{array}{l}\text { ○ } \\
\text { z }\end{array}$ & 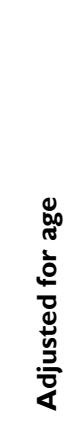 & 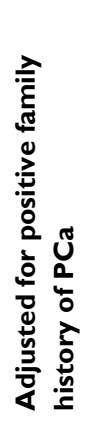 & 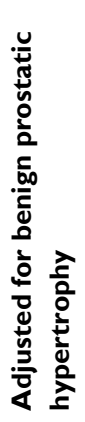 & 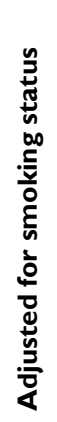 & 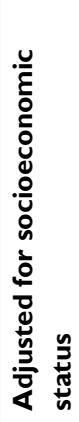 & 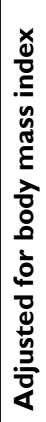 \\
\hline Study and year & \multicolumn{7}{|c|}{ Assessment of the main biases } & \multicolumn{6}{|c|}{ Analysis of PCa risk } \\
\hline Schuurman et al, $1999^{2}$ & & & & & & & 6 & & & & & & \\
\hline Schoonen et al, $2005^{9}$ & & & & & & & 8 & & & & & & \\
\hline Velicer et al, $2006^{15}$ & & & & & & & 7 & & & & & & \\
\hline Sutcliffe et al, $2007^{16}$ & & & & & & & 6 & & & & & & \\
\hline Chao et al, 2010 17 & & & & & & & 7 & & & & & & \\
\hline
\end{tabular}

Figure S2 (A) Risk of bias summary of the studies that analyses the association between moderate wine consumption and PCa risk (red: high risk; green: low risk). (B) Risk of bias summary of the studies that analyses the association between moderate white and red wine consumption and PCa risk (red: high risk; green: low risk). Abbreviation: NOS, Newcastle-Ottawa Scale. 


\section{References}

1. Jain MG, Hislop GT, Howe GR, Burch JD, Ghadirian P. Alcohol and other beverage use and prostate cancer risk among Canadian men. Int J Cancer. 1998;78(6):707-711.

2. Schuurman AG, Goldbohm RA, van den Brandt PA. A prospective cohort study on consumption of alcoholic beverages in relation to prostate cancer incidence (The Netherlands). Cancer Causes Control CCC. 1999;10(6):597-605.

3. Sesso HD, Paffenbarger RS, Lee IM. Alcohol consumption and risk of prostate cancer: The Harvard Alumni Health Study. Int J Epidemiol. 2001;30(4):749-755.

4. Albertsen K, Grønbaek M. Does amount or type of alcohol influence the risk of prostate cancer? Prostate. 2002;52(4):297-304.

5. Crispo A, Talamini R, Gallus S, et al. Alcohol and the risk of prostate cancer and benign prostatic hyperplasia. Urology. 2004;64(4):717-722.

6. Platz EA, Leitzmann MF, Rimm EB, Willett WC, Giovannucci E. Alcohol intake, drinking patterns, and risk of prostate cancer in a large prospective cohort study. Am J Epidemiol. 2004;159(5):444-453.

7. Chang ET, Hedelin M, Adami H-O, Grönberg H, Bälter KA. Alcohol drinking and risk of localized versus advanced and sporadic versus familial prostate cancer in Sweden. Cancer Causes Control. 2005;16(3):275-284.

8. Schoonen WM, Salinas CA, Kiemeney LALM, Stanford JL. Alcohol consumption and risk of prostate cancer in middle-aged men. Int $J$ Cancer. 2005;113(1):133-140.

9. Baglietto L, Severi G, English DR, Hopper JL, Giles GG. Alcohol consumption and prostate cancer risk: results from the Melbourne collaborative cohort study. Int J Cancer. 2006;119(6):1501-1504.
10. Benedetti A, Parent M-E, Siemiatycki J. Lifetime consumption of alcoholic beverages and risk of 13 types of cancer in men: results from a case-control study in Montreal. Cancer Detect Prev. 2009;32(5-6): $352-362$.

11. Watters JL, Park Y, Hollenbeck A, Schatzkin A, Albanes D. Alcoholic beverages and prostate cancer in a prospective US cohort study. Am J Epidemiol. 2010;172(7):773-780.

12. McGregor SE, Courneya KS, Kopciuk KA, Tosevski C, Friedenreich CM. Case-control study of lifetime alcohol intake and prostate cancer risk. Cancer Causes Control. 2013;24(3):451-461.

13. Demoury C, Karakiewicz P, Parent M-E. Association between lifetime alcohol consumption and prostate cancer risk: a case-control study in Montreal, Canada. Cancer Epidemiol. 2016;45:11-17.

14. Papa NP, MacInnis RJ, Jayasekara H, et al. Total and beverage-specific alcohol intake and the risk of aggressive prostate cancer: a case-control study. Prostate Cancer Prostatic Dis. 2017;20(3):305-310.

15. Velicer CM, Kristal A, White E. Alcohol use and the risk of prostate cancer: results from the VITAL cohort study. Nutr Cancer. 2006;56(1): 50-56.

16. Sutcliffe S, Giovannucci E, Leitzmann MF, et al. A prospective cohort study of red wine consumption and risk of prostate cancer. Int J Cancer. 2007;120(7):1529-1535.

17. Chao C, Haque R, Van Den Eeden SK, Caan BJ, Poon K-YT, Quinn VP. Red wine consumption and risk of prostate cancer: the California Men's Health Study. Int J Cancer. 2010;126(1):171-179.
Clinical Epidemiology

\section{Publish your work in this journal}

Clinical Epidemiology is an international, peer-reviewed, open access, online journal focusing on disease and drug epidemiology, identification of risk factors and screening procedures to develop optimal preventative initiatives and programs. Specific topics include: diagnosis, prognosis, treatment, screening, prevention, risk factor modification,

Submit your manuscript here: https://www.dovepress.com/clinical-epidemiology-journal

\section{Dovepress}

systematic reviews, risk and safety of medical interventions, epidemiology and biostatistical methods, and evaluation of guidelines, translational medicine, health policies and economic evaluations. The manuscript management system is completely online and includes a very quick and fair peer-review system, which is all easy to use. 